\title{
PEIXES E HOMENS: O PESCAR ALEGÓRICO DE ANTÓNIO VIEIRA
}

\author{
Saulo Gomes Thimóteo ${ }^{1}$
}

\begin{abstract}
Resumo: Há, na obra de António Vieira, um movimento contínuo entre figuras, vindas não somente da Bíblia ou da vida dos santos, mas também de elementos da natureza e da sociedade. Isso se torna visível, por exemplo, no "Sermão de Santo António", escrito em 1654, no qual a figura do santo se conecta a uma variedade de peixes. Cada um deles é evocado por Vieira como uma parte que forma uma rede de metáforas, construindo, por fim, uma pesca destinada aos homens.
\end{abstract}

\section{Palavras-chave: António Vieira, Sermão de Santo António, Peixe, Alegoria}

\section{OF FISH AND MEN: THE ALLEGORICAL FISHING OF ANTÓNIO VIEIRA}

Abstract: There is in António Vieira's works a continuous movement between figures, that came not only from the Bible or the saint's lives, but also from elements of Nature and the society. This can be noted, for example, in the "Sermon of Saint Anthony to the fish", written in 1654, which the saint's figure is connected to a variety of fish. Each one of them is evoked by Vieira as a part that binds a net of metaphors, building at last a fishing that was designated to men.

Key-words: António Vieira, Sermon of Saint Anthony to the fish, Fish, Allegory

Na obra do padre António Vieira, especialmente na parenética, três são os principais jogos elaborados: da palavra parte-se à imagem; da imagem parte-se à palavra; de ambas se geram as proporções. Esses movimentos se dão, especialmente, por meio da apropriação de alegorias e parábolas e a descoberta de associações linguísticas, históricas e culturais com o mote do sermão. E tudo isso, no contexto da retórica argumentativa, dos malabarismos verbais no púlpito com a intenção de persuadir o ouvinte, configura-se como um “discurso engenhoso”, segundo observa António José Saraiva.

E tal engenho se desdobra em todos os níveis do texto: em cada palavra usada, em toda associação feita, nos trechos bíblicos referidos, na apresentação e desenvolvimento das premissas. É o que ocorre, por exemplo, no "Sermão de Santo António" (1654), usualmente conhecido pela denominação "Sermão de Santo António aos Peixes", no qual o recurso principal usado por Vieira é projetar um público diverso do usual como destinatário da mensagem²: assim como Santo António fizera (segundo a lenda) e pregou

\footnotetext{
1 Professor Adjunto II de Teoria Literária e Literaturas de Língua Portuguesa na Universidade Federal da Fronteira Sul - UFFS, campus Realeza/PR.

${ }^{2}$ Isso também seria feito em outros sermões, como o "Sermão pelo bom sucesso das armas de Portugal contra as de Holanda” (1640), em que o interlocutor escolhido não é outro senão o próprio Deus.
} 
aos peixes, já que os homens não o ouviam, o padre Vieira adota a mesma atitude. $\mathrm{Na}$ história do Santo, "Começam a ferver as ondas, começam a concorrer os peixes, os grandes, os maiores, os pequenos, e postos todos por sua ordem com as cabeças de fora da água, António pregava, e eles ouviam.” (VIEIRA, 2015, p. 138). Por sua vez, tomando como mote principal a figura do peixe (e dos peixes), António Vieira propõe uma espécie de reedição desse fato, aproveitando-se, também, da ocasião de pregar na Capela do Senhor Bom Jesus dos Navegantes, em São Luís do Maranhão, igreja localizada à beira da praia.

Seguindo a tradição da retórica greco-romana, como a ars bene dicendi, principiada em Aristóteles, Cícero e Quintiliano, passando pela sua cristianização encetada, dentre outros, por Santo Agostinho e o próprio Santo Antônio, o padre António Vieira constrói, em seus sermões, um jogo de persuasão por meio da concatenação de imagens e conceitos. Um dos elementos retóricos mais utilizados, justamente por criar associações imprevistas e criar uma imagem ao ouvinte/leitor, são os tropos de salto, especialmente a ironia e a alegoria. Conforme Quintiliano define:

O tropo é uma maneira de falar que se desvia de sua significação natural e principal, atribuindo-lhe uma outra, com o fim de reforçar ou embelezar o estilo: ou como o definem a maior parte dos gramáticos, uma expressão que se transporta do lugar onde tem sua acepção própria, para outro onde não a tem. A figura, como o indica claramente o próprio termo, é um modo de expressão, uma mudança operada na linguagem, que se afasta da maneira primordial e corriqueira de se exprimir. (QUINTILIANO apud MALEVAL, 2010, p. 82)

Elaborando tal jeu de scène, de trazer à visão os peixes por meio da história do santo, o exórdio do sermão se encerra, inclusive, com um irônico apagamento do próprio público ouvinte: "Quero hoje à imitação de Santo António voltar-me da terra ao mar, e já que os homens se não aproveitam, pregar aos peixes. O mar está tão perto, que bem me ouvirão. Os demais podem deixar o Sermão, pois não é para eles.” (idem, p. 139).

Assim, no deslocamento pretendido, o jesuíta principia seu périplo que, embora deflagrado pela metáfora do peixe, se vai ampliando num enredamento de tropos de salto alegóricos, podendo dispô-los em três níveis de sentido: a) o "sentido literal", como a rede descritiva construída; b) "outro sentido literal ausente", que adquire significado a partir do repertório do ouvinte/leitor e funciona como a "substância" temática; e c) o "sentido figurado", que é a ponte associativa dirigida ao ouvinte/leitor, buscando-se interligar "a" e 
"b". (cf. HANSEN, 1986, p. 19). Pode-se verificar tal artifício no princípio da cena dos peixes que se comem uns aos outros. Partindo da ação verificável na realidade, da cadeia alimentar entre as espécies de peixes (nível de sentido "a"), António Vieira refere-se a isso como reprimenda aos próprios peixes com os quais interage (nível de sentido "c") e decide ilustrar com exemplos dos homens, que também realizam tal ação (nível de sentido "b”):

Olhai, peixes, lá do mar para a terra. Não, não; não é isso o que vos digo. Vós virais os olhos para os matos e para o Sertão? Para cá, para cá; para a Cidade é que haveis de olhar. Cuidais que só os Tapuias se comem uns aos outros; muito maior açougue é o de cá, muito mais se comem os brancos. Vedes vós todo aquele bulir, vedes todo aquele andar, (...) vedes aquele entrar e sair sem quietação nem sossego? Pois tudo aquilo é andarem buscando os homens como hão de comer e como se hão de comer. (VIEIRA, 2015, p. 150).

Nota-se, também, que há o recurso da dupla interpretação (literal e figurada) do verbo "comer", em que se destaca a forma de antropofagia social que impera em todas as ações humanas ditas civilizadas. Partindo da premissa dos índios como selvagens, Vieira inverte tal visão, ilustrando o tom quase animalesco com que os indivíduos da cidade também podem agir.

Nesse sentido, a distribuição harmônica que Vieira elabora, como organização de seu discurso, vai se formulando segundo uma contraposição de duas ações antagônicas sobre os peixes: louvar e repreender. Para que a alegoria atinja seu efeito retórico, o orador tanto pode não compartilhar as semelhanças, beirando as margens do enigma e transferindo ao ouvinte/leitor a exigência de compreensão, quanto guiá-lo pelas associações propostas. Essa segunda ação se denomina permixta apertis allegoria, e, como aponta Heinrich Lausberg em seus Elementos de retórica literária, tal tropo de salto é aquele em que a figura se mescla com sinais do pensamento pretendido (cf. LAUSBERG, 2011, p. 249). Pode-se considerar, então, esse entrever do pensamento à imagem como uma diretriz da parenética vieiriana, pois há uma forma de didatismo no descortinar de um conceito ou de uma ilustração.

No caso dos peixes do "Sermão de Santo António", eles se dividem conforme uma estruturação binária: louvam-se as suas "virtudes" (imediatamente as contrapondo aos vícios humanos ou às virtudes do santo); e se repreendem os "males" por eles praticados (também em associação com os homens e em antítese a Santo António). Tal estruturação 
reporta-se à praticada pelo próprio Santo Inácio de Loyola, em seus Exercícios espirituais, em que, conforme Roland Barthes salienta em Sade Fourier Loyola "não apenas a matéria ascética é quebrada, articulada ao extremo, mas é também exposta através de um sistema discursivo de anotações, notas, pontos, preâmbulos, precauções, repetições, retornos e colmatagens" (BARTHES, 1990, p. 67). Assim, após estabelecer a divisão entre virtudes e vícios, Vieira propõe nova partição, analisando-se, primeiro, a imagem do peixe, de modo geral, e, na sequência, subdivide-a em imagens de algumas espécies de peixes em particular.

E se tal arquitetura ramificada opera no campo da forma, também se verifica um jogo de espelhamentos na disposição do conteúdo evocado, conforme apontado por Arnaldo José Saraiva:

Há duas espécies de figuras: as que têm força de autoridade, ensinadas por Deus e pela Igreja, ou ainda salientadas pelo exegeta, quando aplica as regras do método alegórico; e as que se podem descobrir na contemplação da Natureza (e também da História). O que as diferencia é que estas, contrariamente àquelas, estão de certa maneira nas coisas: basta ler a Natureza para que se revelem. (SARAIVA, 1980, p. 48)

Por certo que essas modalidades de figuras não são tão delimitadas, de modo que uma mesma imagem presente na Bíblia ou nos discursos religiosos é evocada na Natureza em elementos materiais e concretos, ou vice-versa. Assim, a retórica de Vieira cria uma fusão de ambas as figuras, como estratégia de fazer seus ouvintes "verem" o argumento defendido, com provas e ilustrações. No Sermão, ele começa os louvores precisamente pelo fato de os peixes terem sido as primeiras criaturas que Deus criou, além de serem "os mais" e "os maiores": "Que comparação têm em número as espécies das aves e as dos animais terrestres com as dos peixes? Que comparação na grandeza o Elefante com a Baleia? Por isso Moisés, Cronista da criação, calando os nomes de todos os animais, só a ela nomeou pelo seu ${ }^{3 "}$ (VIEIRA, 2015, p. 140). Interessante apontar que, à pergunta retórica das dimensões da baleia (cuja classificação como mamífero só foi estabelecida no século XIX), sucede uma resposta assertiva proveniente do Gênesis, equiparando-se as esferas e tornando-as, ambas, parte inerente de seu discurso de persuasão.

Descendo aos exemplos das virtudes písceas, a primeira elencada é a anteriormente mencionada na história do milagre de Santo António: "aquela obediência, com que chamados

\footnotetext{
3 “Creavit Deus cete grandia” [Gn 1, 21]. Tradução: “Criou Deus as grandes baleias".
} 
acudistes todos pela honra de vosso Criador e Senhor, e aquela ordem, quietação e atenção, com que ouvistes a palavra de Deus da boca de Seu servo António" (idem, pp. 140-1, grifos nossos). Assim, como animal apresentado sem arroubos, sem bestialidades, Vieira enaltece os peixes em detrimento dos homens irracionais. Constrói-se, então, um equilíbrio em simetria inversa, tanto na ilustração do milagre de Santo António, quanto com outro exemplo ainda mais evidente:

Ia Jonas, pregador do mesmo Deus, embarcado em um navio, quando se levantou aquela grande tempestade; e como o trataram os homens, como o trataram os peixes? Os homens lançaram-no ao mar a ser comido dos peixes, e o peixe, que o comeu, levou-o às praias de Nínive, para que lá pregasse e salvasse os homens. (...) Os homens tiveram entranhas para deitar Jonas ao mar, e o peixe recolheu nas entranhas a Jonas, para o levar vivo à terra (idem, p. 141).

Como método de comprovação e defesa do argumento defendido, cria-se um espelhamento na ordem dos termos (prática muito utilizada por Vieira), de modo a mostrar as ações como antagônicas: homens - mar - peixe, destino trágico de Jonas; peixe - terra homens, destino elevado de Jonas. Tanto na evocação bíblica, quanto na hagiográfica, a figura do peixe aparece imbuído de um propósito maior que ele, como se, embora não dotado de razão, houvesse uma orientação superior que plenamente seguiu. Tal figura, inclusive, está presente na própria mitologia cristã, com a imagem dos "pescadores de homens" com que Cristo chama os Apóstolos. Além disso, "a palavra grega Ichtus (= peixe) é, com efeito, tomada pelos cristãos como ideograma, sendo cada uma das cinco letras gregas vista como a inicial de palavras que se traduzem por: Jesus Cristo, Filho de Deus, Salvador, Iesus Christós Theou Uios Soter." (CHEVALIER, GHEERBRANT, 1989, p. 704).

Para além dos exemplos de matéria religiosa, como já mencionado por Saraiva, António Vieira também ilumina os argumentos com luzes naturais e científicas. No caso, evocando, possivelmente a Historia Animalium, de Aristóteles, aponta a segunda virtude dos peixes, que é a de não se deixarem domar ou domesticar. Se todos os outros animais, de alguma forma, se adaptam ao convívio humano, os peixes "lá se vivem nos seus mares e rios, lá se mergulham nos seus pegos, lá se escondem nas suas grutas, e não há nenhum tão grande, que se fie do homem, nem tão pequeno, que não fuja dele.” (VIEIRA, 2015, pp. 141-2). Nessa não familiaridade com os homens reside, na visão vieiriana, a matéria de 
grande louvor, pois todos os animais, tanto da terra, quanto dos ares, do rouxinol ao leão, quando domesticados, são também presos, enjaulados e encarcerados.

Em exemplo que isso ilustra, Vieira apresenta a passagem bíblica em que os animais todos participam: a arca de Noé.

\begin{abstract}
Dos leões escaparam dois, leão e leoa, e assim dos outros animais da terra; das águias escaparam duas, fêmea e macho, e assim das outras aves. $\mathrm{E}$ dos peixes? Todos escaparam; antes não só escaparam todos, mas ficaram muito mais largos que dantes, porque a terra e o mar, tudo era mar. Pois se morreram naquele universal castigo todos os animais da terra e todas as aves, porque não morreram também os peixes? Sabeis porquê? Diz Santo Ambrósio: porque os outros animais, como mais domésticos, ou mais vizinhos, tinham mais comunicação com os homens; os peixes viviam longe e retirados deles. (idem, p. 142).
\end{abstract}

Assim, com a associação da história bíblica e o respaldo de Santo Ambrósio, o pregador confirma seu argumento de que os pecados dos homens contaminam e castigam até os que com eles convivem e que os peixes, por se isolarem, mantêm-se puros e, por extensão, mais próximos de Deus. Inclusive, por um volteio interpretativo, Vieira coloca Santo António como um exortador dessa qualidade e aplicador disso à própria vida, fugindo ao convívio humano, como se a imagem do santo se fosse associando intimamente à dos peixes.

Como se pode notar, António Vieira dispõe os textos sagrados como repositório de alegorias, parábolas e metáforas. Assim, transportando-se do Gênesis aos Evangelhos, dos profetas ao Apocalipse, além dos exegetas bíblicos, toda imagem que se puder conectar com o assunto escolhido, no caso, os peixes e as águas, será utilizada com vistas à formulação argumentativa, orquestrando-se ao todo sinfônico que é o sermão.

E se houve o momento de enaltecimento de duas virtudes gerais, na sequência o padre desce ao particular, propondo quatro exemplos de espécies com características louváveis. A primeira, na verdade, ainda se encontra no plano do símbolo, pois é o peixe do rio Tigre, mencionado no livro de Tobias. Embora não nomeado, cogita-se que se trata da espécie lúcio, pois é um peixe de grande voracidade ainda existente na região e que pode atingir o tamanho de um homem. Ao vencer o peixe que o atacava, um anjo aconselha Tobias que guarde as entranhas: "Se tu puseres um pedacinho do seu coração sobre brasas acesas, o seu fumo afugenta toda a casta de demônios (...), de sorte que não tornam mais a chegar a eles. O fel é bom para untar os olhos que têm algumas névoas, e sararão." 
(TOBIAS, 6, 8). A partir disso, António Vieira tece uma conexão alegórica entre as ações do peixe e as ações do santo, dirigindo-se aos homens:

(...) se a este Peixe o vestiram de burel, e o ataram com uma corda, pareceria um retrato marítimo de Santo António. (...) Se vós lhe abrísseis esse peito, e lhe vísseis as entranhas, como é certo que havíeis de achar, e conhecer claramente nelas que só duas coisas pretende de vós, e convosco: uma é alumiar, e curar vossas cegueiras; e outra lançar-vos os Demónios fora de casa. (VIEIRA, 2015, p. 144).

O jogo vieiriano não apenas compara ambos, mas estende à dupla significação de cada figura, que ocorre em dois planos, conforme apontado por Saraiva: "o da sua existência própria e o da existência do conceito.” (SARAIVA, 1980, p. 48). Assim, o peixe e suas propriedades operam no plano natural (o coração e o fel atuando como elementos físicos), mas coadunados a um plano simbólico (o componente mágico disso resultante). E o Santo, por meio de sua pregação referida, ganha as associações simbólicas atribuídas ao peixe bíblico.

Por fim, fingindo a correção de um autoengano, Vieira encerra a figura desse primeiro peixe, voltando ao seu público original: "Mas ah sim, que me não lembrava! Eu não vos prego a vós, prego aos peixes" (VIEIRA, 2015, p. 144). O encaminhamento desloca-se, então, da Escritura para a História natural, evocando-se três espécies de peixes: a Rémora; o Torpedo; e o Quatro-Olhos.

O primeiro, de nome científico Echeneis naucrates, cujo segundo termo significa "o que governa barcos", é um peixe pequeno de forma achatada, com uma ventosa na parte superior do corpo e que se fixa em animais maiores ou em embarcações. Com isso, António Vieira louva essa virtude, apontando que "não sendo maior de um palmo, se se pega ao leme de uma Nau da Índia, apesar das velas e dos ventos e de seu próprio peso e grandeza, a prende e amarra mais que as mesmas âncoras, sem se poder mover nem ir por diante" (idem, p. 145). Com esse exemplo, efetivamente verificável na realidade, ele cria a associação com a língua de Santo António, citando o verso de São Gregório Nazianzeno dedicado ao santo: "Lingua quidem parva est, sed viribus omnia vincit" (idem, ibidem). E estabelece, como premissa de comparação, a fala do Apóstolo Santiago, que compara a língua ao leme da Nau e ao freio do cavalo.

\footnotetext{
4 Tradução: “A língua é pequena, mas em força tudo vence”.
} 
Assim, unindo o elemento natural da imagem da Rémora ao poder das palavras da língua de Santo António, o padre Vieira descobre as correlações entre ser leme (guiar) e ser freio (conter). E se o peixe consegue realizar ambas as ações quando se liga a um barco, aponta-se que o santo também o faz recorrendo a quatro Naus alegóricas: a Fortuna, a Vingança, a Cobiça e a Sensualidade. Na segunda delas, por exemplo:

Quantos embarcados na Nau Vingança com a artilharia abocada e os bota-fogos acesos, corriam enfunados a dar-se batalha, onde se queimariam ou deitariam a pique, se a Rémora da língua de António lhes não detivesse a fúria, até que composta a ira e o ódio, com bandeiras de paz se salvassem amigavelmente? (idem, ibidem).

Observa-se que, na forma de uma pergunta, cada Nau é caracterizada e demonstrase como, caso não houvesse a intervenção e condução/retenção de Santo António, os incautos passageiros pereceriam. Dessa forma, revela-se o valor do santo, por meio das projeções efetuadas por sua "língua-rémora".

$\mathrm{Na}$ sequência, o segundo peixe é evocado: o Torpedo, também chamado em Portugal de tremelga-de-olhos ou trememão, com o nome científico de Torpedo torpedo. A virtude louvada pelo padre é precisamente o fato desse peixe lançar uma descarga elétrica pelo contato, causando um entorpecimento da presa ou do predador. Então, após o binômio "guiar/conter", surge a ação de "tremer", como descrita na cena: "Está o pescador com a cana na mão, o anzol no fundo e a boia sobre a água, e em lhe picando na isca a Torpedo, começa a lhe tremer o braço. (...) Passa a virtude do peixezinho, da boca ao anzol, do anzol à linha, da linha à cana, e da cana ao braço do pescador.” (idem, p. 146) Na gradação estabelecida se sugere a imagem da transmissão, sendo que o tremor se torna símbolo de desassossego ou, num contexto mais religioso, da necessidade de remissão.

Acrescentando esse significado espiritual ao verbo tremer, Vieira aponta como Santo António também se assemelha ao Torpedo, tendo feito vinte e dois pescadores tremerem com um sermão e confessarem, arrependerem-se e emendarem-se. Com isso, a virtude elétrica do peixe converte-se em virtude iluminada do santo, ambas a serem transmitidas e absorvidas por aqueles que foram atingidos. E aqui reside uma crítica que o padre faz aos pregadores (como também seria reiterado com mais profundidade no Sermão da Sexagésima, pregado seis meses depois, no início de 1655): seria função dos padres fazerem os ouvintes tremerem com os sermões, pois eles seriam os pescadores de homens. 
Mas António Vieira não sente a intensidade necessária desse choque: "Quem dera aos pescadores do nosso elemento, ou quem lhes pusera esta qualidade tremente, em tudo o que pescam na terra! Muito pescam; mas não me espanto do muito: o que me espanta é que pesquem tanto e que tremam tão pouco. Tanto pescar e tão pouco tremer?” (idem, ibidem).

Tal disparidade percebida entre a quantidade e a qualidade dessa pesca se dirige, especialmente, no sentido de não haver o desenvolvimento de um tremer. No caso, Vieira aponta a necessidade de um tremer interno inicial, como acontece no Torpedo, a se transferir, dirigir a quem é devido. Este se torna, então, o silogismo possível dessa alegoria evocada: Premissa maior (natural) - O Torpedo possui em seu interior a capacidade de fazer o pescador tremer; Premissa maior (religiosa) - Santo António possuía em seu interior a capacidade de fazer os pescadores tremerem; Premissa menor - Os atuais pescadores de homens não conseguem fazer os demais tremerem; Conclusão - Falta aos atuais pescadores essa capacidade interior.

Por fim, após o direcionamento da Rémora e o despertar do Torpedo, Vieira evoca um peixe brasileiro: o Quatro-Olhos, também conhecido como Tralhoto. De nome científico Anableps microlepis, sendo que o primeiro termo sugere a questão do "olhar duplo" e o segundo uma dimensão reduzida. No caso, o peixe fica na superfície da água e seus olhos dividem-se em duas secções, como uma ampulheta, com cada parte contando com uma pupila independente, o que confere duas visões: acima e abaixo da água.

A partir dessa sugestão, António Vieira inicialmente aponta uma análise natural para essa "virtude":

estes peixezinhos, que sempre andam na superfície da água, (...) como têm inimigos no mar e inimigos no ar, dobrou-lhes a Natureza as sentinelas, e deu-lhes dois olhos, que direitamente olhassem para cima, para se vigiarem das aves, e outros dois, que direitamente olhassem para baixo, para se vigiarem dos peixes. (idem, p. 147).

Tomado como um animal superior à águia e ao lince, que mesmo com grande visão possuem somente dois olhos, Vieira louva essa grande capacidade do Quatro-Olhos e acrescenta a autorreflexão acometida, diante da união das visões superior e inferior: "Esta é a pregação, que me fez aquele peixinho, ensinando-me que se tenho Fé, e uso de razão, só devo olhar direitamente para cima e só direitamente para baixo: para cima, considerando 
que há Céu, e para baixo, lembrando-me que há Inferno.” (idem, pp. 147-8). Extrapolando a questão dos perigos do ar e da água, o padre usa esse novo peixe para exaltar essa forma de não perder de vista o necessário para escapar das vaidades do mundo e garantir a salvação da alma: olhando concomitantemente para os dois hemisférios do além-mundo, buscam-se os cuidados em alcançar o Céu e atentam-se às investidas do Inferno.

Nesse cardume de peixes louváveis, o que se extrai, tanto no que tange a cada espécie particular, quanto nas correlações estabelecidas com Santo António, é justamente a capacidade inerente ao ser e sua atuação sobre o elemento externo. Dessa forma, tem-se a Rémora com sua grande força que contém, o Torpedo com seu amplo choque que revela e o Quatro-olhos com seu duplo poder que observa. Todo o jogo se constrói em torno de palavras-conceito, às quais se associam imagens, que se desdobram em novos conceitos, que sugerem novas imagens, fazendo com que o sermão funcione como um todo orgânico com cada parte cumprindo o papel que lhe fora destinado.

Conforme António José Saraiva observa, “o autor consegue dizer tudo o que quer sem desconsiderar a palavra, sem forçá-la ou desprezá-la, mas pelo contrário, conhecendoa perfeitamente, manejando com delicadeza toda sua engrenagem, despertando todo o seu corpo, liberando-lhe toda a energia." (SARAIVA, 1980, p. 29). Uma vez que, em um sermão, tudo é palavra, a expressividade que se confere a cada argumento, imagem ou conceito surge como uma forma de prestidigitação, capaz de persuadir o leitor/ouvinte de tal forma que o faça deduzir o raciocínio que o pregador induziu.

Após todo o edifício do louvor, para que o equilíbrio se garanta, Vieira passa a formular o edifício da reprimenda. Essa estrutura proporcional, em conexão com os Exercícios inacianos, acompanha os princípios da retórica clássica e dos jogos alegóricos. Roland Barthes, na análise da obra de Santo Inácio de Loyola, salienta que não há somente uma divisão contínua e quase obsessiva da matéria, mas sim a sua articulação, ou melhor, o seu discernimento. Para o crítico francês, "discernir é distinguir, separar, apartar, limitar, enumerar, avaliar, reconhecer a função fundadora da diferença” (BARTHES, 1990, p. 52). Em Vieira, esse reconhecimento passa por leitura de cada parte de sua matéria, dividindo-a de modo equitativo e elaborando um escrutínio de cada uma.

João Adolfo Hansen observa tal estruturação, salientando que 
termos. Isso pressupõe que cada termo - como "visão" ou "intelecção" - seja pensado logicamente, isto é, como comparação de duas relações entre quatro termos pensados dois a dois (HANSEN, 1986, p. 36).

No caso do sermão de Santo António, como já apontado anteriormente, o que se estabelece como proporção é o ato de repreender como contraponto do ato de louvar, e o movimento em ambas de partir do elemento geral (dividido em dois pormenores) para os exemplos particulares (com quatro espécies em cada). Com isso, a rede entretecida por Vieira costura-se pelo equilíbrio na figura ampla e nos nós que também se vão equivalendo.

O primeiro dos pormenores apontados como repreensão aos peixes é o supracitado ato de "comer uns aos outros". E o canibalismo projetado por António Vieira nos peixes ainda se torna mais alegórico quando o padre aponta que "os grandes comem os pequenos. Se fora pelo contrário, era menos mal. Se os pequenos comeram os grandes, bastara um grande para muitos pequenos; mas como os grandes comem os pequenos, não bastam cem pequenos, nem mil, para um só grande.” (VIEIRA, 2015, p. 149). Essa primeira lástima que se apresenta no sermão reverbera a exploração dos fortes sobre os fracos. Por certo que a exploração dos índios, uma das contínuas denúncias de Vieira, reverbera nessa alegoria dos muitos "pequenos" para servir a um "grande", mas tal comparação ganha ares universais, espraiando-se para toda forma de exploração social dos grandes (ricos) sobre os pequenos (pobres).

Assim, nesse espelhamento que Vieira vai desdobrando por todo o sermão, reside o modo maneirista de transpor o mundo e seus fenômenos em imagens outras. Conforme Gustav Hocke, em Maneirismo na literatura, aponta, é através da metáfora (e da alegoria, como sua expansão) que "o caos dos fenômenos aparece através de um engenhoso balé de metáforas artificialmente ordenado." (HOCKE, 2011, p. 112). Assim, o jogo engenhoso de aproximar e contrapor elementos díspares - como seriam os peixes sendo ouvintes e o público servindo de exemplo - desvela-se num todo harmônico.

Na cena evocada, do movimento de "comerem-se uns aos outros", Vieira realiza, em seu discurso, uma inversão vetorial com relação a Santo Agostinho, pois este, "que pregava aos homens, para encarecer a fealdade deste escândalo, mostrou-lho nos peixes; e eu que prego aos peixes, para que vejais quão feio, e abominável é, quero que o vejais nos homens." (VIEIRA, 2015, p. 150). Então, pela reordenação do discurso engenhoso 
vieiriano, os homens servem de exemplo aos peixes que, retoricamente, servem de exemplo aos homens. E a descrição escolhida são as ações dos outros sobre a morte alheia:

\begin{abstract}
Morreu algum deles, vereis logo tantos sobre o miserável a despedaçá-lo, e comê-lo. Comem-no os herdeiros, comem-no os testamenteiros, comem-no os legatários, comem-no os acredores; (...) come-o a mesma mulher, que de má vontade lhe dá para a mortalha o lençol mais velho da casa, come-o o que lhe abre a cova, o que lhe tange os sinos, e os que cantando o levam a enterrar: enfim, ainda ao pobre defunto o não comeu a terra, e já o tem comido toda a terra. (idem, ibidem, grifos nossos).
\end{abstract}

$\mathrm{Na}$ continuação da lástima dessa falha humana, espelhada nos peixes, Vieira propõe, como forma de emenda, que os peixes se lembrem de que, mesmo que algum deles coma um peixe menor, sempre haverá um maior que também lhe poderá comer. E finda, recorrendo à lenda de Santo António, apontando como todos os peixes, de todas as espécies, encontravam-se unidos e "amigos" ouvindo o seu sermão.

Se essa primeira reprimenda reside na relação hierárquica e de força interpessoal (ou interpiscial), a segunda se torna mais ampla e da tendência ao autoengano: a ignorância e a cegueira de se deixar pescar por ilusões. Descrevendo um pedaço de pano cortado em tiras como a isca, Vieira mostra como o peixe abocanha cegamente o anzol oculto e se deixa apanhar e morrer. Criando uma resposta de seus interlocutores, o padre cria a ponte para chegar aos homens: "Dir-me-eis que o mesmo fazem os homens. Não vo-lo nego." (idem, p. 154), e assim apresenta como os homens também se deixam enganar por meros pedaços de pano. O primeiro caso sendo dos soldados, que se alistam para carregar uma insígnia ao peito e morrem trespassados nas batalhas: "[A vaidade] põe por isca nas pontas desses piques, desses chuços, e dessas espadas dois retalhos de pano, (...) e os homens por chegarem a passar esse retalho de pano ao peito não reparam em tragar, e engolir o ferro." (idem, ibidem). Interessante notar que a imagem construída por António Vieira se assemelha à própria pescaria tradicional, com o ferro (anzol) se ocultando por trás da insígnia (isca), proporcionando à vaidade essa ilusão de pescar os homens.

Além da vaidade de lutar por uma casa, a outra isca de panos é de natureza mais cotidiana e trivial:

Vem um Mestre de Navio de Portugal com quatro varreduras das lojas, com quatro panos, e quatro sedas, que já se lhes passou a era, e não têm gasto: e que faz? Isca com aqueles trapos aos moradores da nossa terra; 
(...) e ali ficam engasgados, e presos, com dívidas de um ano para outro ano, e de uma safra para outra safra, e lá vai a vida. (idem, p. 155, grifos nossos).

A escolha vocabular, intencionalmente, estabelece-se como se as pessoas fossem fisgadas. Com isso, a imagem das vaidades do mundo como iscas que pescam os homens fica associada aos peixes que cegamente se deixam apanhar e António Vieira executa a alegoria de lastimar os peixes para alertar os ouvintes. O contraponto apresentado na figura de Santo António, ainda sob a mesma temática de panos e pescas, vem no sentido do pregador evidenciar como o santo despiu-se das roupas e galas da nobreza e vestiu-se com o hábito franciscano: "Com aquela corda, e com aquele pano pescou ele muitos, e só estes se não enganaram, e foram sisudos.” (idem, ibidem). Conforme já mencionado anteriormente, a evolução dos argumentos nos sermões vieirianos dá-se pela égide da alegoria, tomada nas partes que a compõem, e elaborando-se conjuntamente uma “anatomia da palavra” (SARAIVA, 1980, p. 13). Tal expressão mostra-se altamente representativa, uma vez que se Isto é, desmontam-se os significados e associações possíveis de uma palavra, de seu conceito e de sua imagem, com vistas a criar uma exemplificação em rede, como aqui em torno da figura do peixe e das ações de comer e deixar-se pescar.

Para além dessas faltas, e obedecendo à disposição equilibrada das partes, Vieira passa à dissecação particular de quatro seres aquáticos, tanto por suas características, quanto por seus nomes: o Roncador; o Pegador; o Voador; e o Polvo.

O primeiro, cujo nome científico é Trachelyopterus oncinus, tem como principal característica natural o ato de emitir um ronco muito alto em intensidade, como forma de acasalamento e quando ameaçado por predadores. Diante desse ronco, já apresentado no próprio nome do peixe, António Vieira revela o espanto quando comparado ao seu diminuto tamanho físico: "É possível que sendo vós uns peixinhos tão pequenos haveis de ser as roncas do mar? (...) É regra geral que Deus não quer Roncadores, e que tem particular cuidado de abater, e humilhar aos que muito roncam.” (VIEIRA, 2015, p. 156). Pela significação do verbo, associa-se o roncar ao ato de fazer grande alarido. Da imagem do ser de pouco tamanho e muito ronco, o padre transporta-se à figura de São Pedro, que enfrentou o exército de soldados romanos que queriam prender Jesus ${ }^{5}$, mas que uma mulher, perguntando se era discípulo, fê-lo tremer e negar. E nessa aproximação de

\footnotetext{
${ }^{5}$ Passagem presente em João, 18, 10-11.
} 
contrários, evoca a cena no horto de Getsêmani, em que Pedro adormeceu após uma hora de vigília. A isso, Vieira conclui:

Pouco há tanto roncar, e agora tanto dormir? Mas assim sucedeu. O muito roncar antes da ocasião é sinal de dormir nela. Pois que vos parece, irmãos Roncadores? Se isto sucedeu ao maior pescador, que pode acontecer ao menor peixe? Medi-vos, e logo vereis quão pouco fundamento tendes de brasonar, nem roncar. (idem, ibidem).

O alerta dado aos peixes e exemplificado na Bíblia se transmuta aos ouvintes pela premissa da inutilidade do ronco, pois ele não se constitui ação efetiva, mas sim apenas bravata ilusória. Lançando o exemplo de Golias (sendo o correspondente humano da Baleia), o padre comprova como o muito ronco arrogante acabou vencido por uma pedra desferida por um pastor. E também como os roncadores humanos se incham ou pelo saber (com o exemplo de Caifás) ou pelo poder (com o exemplo de Pilatos), mas que tais roncos não têm a mesma intensidade do saber e do poder calados, presentificados na vida e ações de Santo António. Ao que Vieira conclui que melhor é o calar e agir do que o somente bradar.

Após tal argumentação labiríntica, em que o nome-conceito do peixe Roncador dá vazão à crítica da soberba vazia, o padre António Vieira realiza uma nova prestidigitação, fazendo com que o mesmo peixe louvado anteriormente seja também repreendido. Se antes a virtude da Rémora foi enaltecida, como guia e freio, a falha do Pegador (sendo apenas um outro nome dado ao mesmo peixe) é justamente pegar-se com um peixe maior para lhe aproveitar as sobras. A essa ação da natureza, Vieira compara com a ação da sociedade, pois vê que "não parte Vizo-Rei, ou Governador para as Conquistas, que não vá rodeado de Pegadores, os quais se arrimam a eles, para que cá lhes matem a fome, de que lá não tinham remédio" (idem, p. 157). Se no campo da natureza isso se descreve como comensalismo, no campo da corte o padre revela um parasitismo.

Como exemplificação de tal ação, três imagens são construídas, apontando como tal associação é danosa e deveria ser evitada pelos peixes (e indiretamente pelos homens): inicialmente, descreve a pesca de um Tubarão, em que este comeu a isca e morreu, ao passo que os Pegadores também foram levados e mortos com ele; em associação, usa de uma passagem do Evangelho de Mateus, sobre a morte de Herodes ("Morto Herodes, (...) morreram os que procuraram tirar a vida do menino" [Mt, 2, 19-20]) para evidenciar como 
os peixes menores perecem sem aquele do qual tiram o sustento; a terceira reporta-se ao Gênesis:

\begin{abstract}
Que morra o Tubarão, porque comeu, matou-o a sua gula; mas que morra o Pegador pelo que não comeu: é a maior desgraça, que se pode imaginar! Não cuidei que também nos peixes havia pecado original. Nós os homens fomos tão desgraciados, que outrem comeu e nós o pagamos. Toda a nossa morte teve princípio na gulodice de Adão, e Eva; e que hajamos de morrer pelo que outrem comeu, grande desgraça! (idem, p. 159).
\end{abstract}

Assim, fundindo sob a mesma ideia (o menor que se aproveita do maior acaba sofrendo as consequências se esse lhe falta) imagens múltiplas como o Tubarão com os Pegadores, o Governador com sua corte, Herodes com seus súditos e Adão com seus filhos, António Vieira maneja um conceito em metamorfose, revelando que a essência não se modifica, mas que é identificável em diversas estruturas simbólicas.

A alternativa a essa falha do peixe Pegador encontra-se, mais uma vez, na figura de Santo António. No caso, Vieira analisa a própria imagem de Santo António, com o Menino Jesus ao colo, em que se aplica a dúvida de qual dos dois seria o pegador: "parece que é Cristo; porque o menor é sempre o que se pega ao maior, e o Senhor fez-Se tão pequenino, para Se pegar a António. Mas António também se fez Menor ${ }^{6}$, para se pegar mais a Deus." (idem, p. 158). Com isso, o santo e o menino se mostram tanto como pegador quanto peixe maior, criando uma forma de mutualismo, em que ambos se complementam e influem um sobre o outro.

O terceiro a ser evocado é o peixe Voador. Embora não se apresente a espécie, são os exemplares da família Exocoetidae, cujo significado é "não submergido", isto é, que pode se manter acima da água. Essa aspiração a sair do seu elemento é a característica repreendida por Vieira, que vê nisso uma ambição desmedida que acaba por perdê-los, uma vez que "não sois ave, senão peixe", e joga com elementos comparativos entre esse peixe e os demais:

Aos outros peixes do alto, mata-os o anzol, ou a fisga; a vós sem fisga, nem anzol, mata-vos a vossa presunção, e o vosso capricho. Vai o navio navegando, e o Marinheiro dormindo, e o Voador toca na vela, ou na corda, e cai palpitando. Aos outros peixes mata-os a fome, e engana-os a

\footnotetext{
${ }^{6}$ Outra nomenclatura para a Ordem dos Franciscanos: Ordem dos Frades Menores.
} 


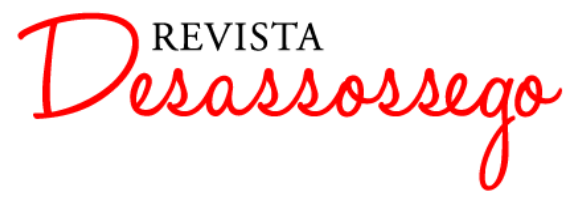

isca; ao Voador mata-o a vaidade de voar, e a sua isca é o vento. (idem, pp. 159-60).

O alerta deflagrado por Vieira desdobra-se na convicção de que aquele que quer mais do que necessita, acaba perdendo tanto o que almejava, quanto o que já possuía. A lástima que se extrai de tal atitude, num trânsito altamente simbólico, formula-se no tríptico: “A Natureza deu-te a água, tu não quiseste senão o ar, e eu já te vejo posto ao fogo.” (idem, p. 160). Lembrando-se de que o padre persiste na exortação aos peixes, não aos homens, é interessante notar como tal movimento alegórico da personificação, entretecido por todo o sermão, naturaliza-se na linguagem empregada, de modo que os peixes se tornam interlocutores em tudo similares aos humanos, inclusive com razões de louvor e reprimenda igualmente aplicáveis.

No caso do Voador, três exemplos de homens se apresentam, no sentido de provar os perigos de persistir no erro de querer voar não devendo e a graça de poder voar não querendo. Inicia com Simão Mago, personagem com dotes mágicos, que aparece nos Atos dos Apóstolos querendo comprar as graças do Espírito Santo com dinheiro. Conforme narrado por São Máximo, numa ocasião Simão Mago principiou a voar sobre Roma, mas São Pedro o fez cair, fazendo com que quebrasse os pés. Da história, António Vieira remata, a título de asseverar o argumento até então construído, "E Simão tem pés, e quer asas; pode andar, e quer voar; pois quebrem-se-lhe as asas para que não voe, e também os pés, para que não ande. Eis aqui, Voadores do mar, o que sucede aos da terra, para que cada um se contente com o seu elemento.” (idem, p. 161). Dos apóstolos, parte à mitologia grega, em que menciona Ícaro, como exemplo máximo da imprudência e que, como o peixe Voador, ganhou asas sem saber como usá-las e afogou-se.

Como forma de síntese, o terceiro homem evocado é Santo António, que ganhou, simbolicamente, as asas da sabedoria natural e sobrenatural. Sendo que o santo, ao invés de voar para cima, como o fizeram todos os outros exemplos danosos, voou para baixo, recolhendo as asas. Assim, desviando-se da ambição, melhor conseguiu compreender seu lugar e seu papel.

Desse modo, extraindo dos peixes os símbolos da arrogância que não age, do conluio que mata e da ambição que dana, António Vieira recrimina todas essas atitudes, louvando o santo como contraponto não pelo fato de ter pregado aos peixes, conforme a 
hagiografia conta, mas sim pelos relatos das ações de sua vida, tornando-o exemplo a se seguir por peixes e por homens.

O último animal apontado, embora não sendo necessariamente um peixe, mas assim tratado no contexto de um sermão do século XVII, é o Polvo. Esse molusco, na visão vieiriana, constitui-se como o maior traidor do mar. A descrição inicial dá-se por meio de associações: "Com aquele seu capelo na cabeça parece um Monge, com aqueles seus raios estendidos, parece uma Estrela, com aquele não ter osso, nem espinha, parece a mesma brandura, a mesma mansidão.” (idem, p. 162). Mas o discurso que Vieira propõe formula-se pela denúncia irônica do embuste, pois a traição do Polvo se dá pelo disfarce da cor, de modo a ocultar-se numa pedra à espera da presa e no engano súbito de aprisioná-la com seus tentáculos.

Novamente usando dos recursos bíblicos, António Vieira cria a associação com o traidor da Bíblia por excelência: Judas. Indo além, argumenta que o Polvo se revela pior que Judas em suas ações: "Judas abraçou a Cristo, mas outros O prenderam: o Polvo é o que abraça, e mais o que prende. Judas com os braços fez o sinal, e o Polvo dos próprios braços faz as cordas. (...) Vê, Peixe aleivoso, e vil, qual é a tua maldade, pois Judas em tua comparação já é menos traidor" (idem, ibidem). Se a traição de Judas se deu às claras, a do Polvo se dá às escuras e com a vítima ludibriada.

A essa imagem, carregada na ênfase retórica, António Vieira parece chegar à conclusão associativa desejada, pois aponta que tal animal habita no mais puro e cristalino dos elementos, espelho natural da terra e do céu. Indaga-se como é possível que nesse ambiente "se crie, se conserve, e se exercite com tanto dano do bem público um monstro tão dissimulado, tão fingido, tão astuto, tão enganoso, e tão conhecidamente traidor?” (idem, p. 163). Então, mutatis mutandis, o padre nota (através dos peixes) que essa terra também possui falsidades, ciladas e traições, assim como sujeitos similares ao Polvo. Como desvio a essa tendência, e emenda dirigida aos homens-polvo, surge novamente a figura de Santo António, com Vieira o exaltando aos peixes: "vereis nele o mais puro exemplar da candura, da sinceridade, e da verdade, onde nunca houve dolo, fingimento ou engano. $\mathrm{E}$ sabei também que para haver tudo isto em cada um de nós, bastava antigamente ser Português, não era necessário ser Santo.” (idem, ibidem, grifos nossos). Remetendo à nacionalidade do santo, surge essa crítica final, com as virtudes ancestrais portuguesas deslocadas, de modo que, se 
antes fora capaz de gerar santos, nos dias de Vieira os homens estão tão imersos em seus vícios que parecem aqueles aos quais Santo António tentou pregar.

Em todo o sermão, como algo também perceptível por toda a parenética vieiriana, o tema eleito se foi apresentando, desmembrando e sendo considerado em cada parte. As figuras dos peixes foram exploradas e sendo associadas à figura de Santo António, motivo central do sermão, de tal forma que, ao final, todas as compreensões que se foram construindo ajudam a compor a compreensão global dos peixes como projeções das ações humanas. Isso se coaduna com a noção da agudeza do discurso engenhoso, conforme João Adolfo Hansen aponta, evocando Artificio y arte de ingenio, de Baltasar Gracián, no artigo “Agudezas seiscentistas": “A agudeza que resulta da comparação de conceitos (...) é 'raio' e 'luz' gerados pelo 'entendimento' do autor discreto, cujo juízo compara conceitos para decompô-los dialeticamente (...) e estabelecer semelhanças e diferenças entre eles." (HANSEN, 2002, p. 60). A discrição de Vieira, nesse caso, reside na sua "sutileza do pensar", ao deslocar-se aos peixes, e não aos homens, persistindo no jogo dramático como forma de evidenciar o conceito pretendido: não somente pregar sobre Santo António, mas pregar como Santo António, tomando esse novo público como mote do sermão.

Com isso, após a iluminação sobre os louvores e repreensões pressentidas tem lugar a despedida do auditório písceo. E duas últimas comparações se fazem: a primeira, entre os peixes e os outros animais; a segunda, entre os peixes e os homens. Em análise dos animais, recorrendo ao Levítico, Vieira aponta quais são os animais escolhidos por Deus para serem sacrificados a Ele: e os peixes não estão nesse rol. E a razão encontrada é que, ao passo que todos os outros animais poderiam ir vivos até o sacrifício, os peixes já chegariam mortos. Então, como conclusão decorrente, o padre aponta que "coisa morta não quer Deus que se Lhe ofereça, nem chegue aos Seus Altares. (...) melhor é não chegar ao Sacrifício, que chegar morto.” (VIEIRA, 2015, p. 162), de modo que, alegoricamente, os peixes se tornam mais reverentes por não se sacrificarem.

Da mesma forma, ao comparar os peixes com os homens, elegendo a si mesmo como elemento humano, destaca os modos de ofender a Deus, em contraposição às ações dos peixes:

Eu falo, mas vós não ofendeis a Deus com as palavras; eu lembro-me, mas vós não ofendeis a Deus com a memória; (...) eu quero, mas vós não ofendeis a Deus com a vontade. (...) Vós não haveis de ver a Deus, e 
podereis aparecer diante Dele muito confiadamente, porque $\mathrm{O}$ não ofendestes; eu espero que $\mathrm{O}$ hei de ver; mas com que rosto hei de aparecer diante do Seu divino acatamento, se não cesso de $\mathrm{O}$ ofender? (VIEIRA, 2015, p. 165).

Com isso, embora os peixes sejam o elemento comum em ambas as comparações, Vieira insere dois outros fatores: os homens, que ofendem a Deus ou por trazerem a alma já morta ao altar ou por trazerem palavras, lembranças e vontades também ofensivas; e Deus, que criou os peixes sem deles não receber qualquer ofensa.

A função clássica do sermão é persuadir o ouvinte (ou leitor) da validade dos argumentos por meio da lógica inerente ao raciocínio proposto e da retórica existente na criação de figuras e associações, em prol de um conceito. Nesse sentido, e conforme Gustav Hocke aponta em Maneirismo na literatura, "Concetto trata-se de um feliz casamento entre inspiração e inteligência, intuição e sagacidade, desmoronamento e construção, ideia e arquitetura, ou seja, de uma antitética lírico-dramática" (HOCKE, 2011, p. 234). António Vieira, então, elegendo o peixe, em suas múltiplas faces e nas variadas espécies, como seu conceito central, não apenas desvenda associações que transitam por todos os livros da Bíblia e pela hagiografia de Santo António, mas também formula suas criações segundo o que vê na natureza dos seres e nos jogos da linguagem possíveis.

\section{REFERÊNCIAS BIBLIOGRÁFICAS}

BARTHES, Roland. Sade, Fourier, Loyola. Trad: Mário Laranjeira. São Paulo: Brasiliense, 1990.

CHEVALIER, Jean; GHEERBRANT, Alain. Dicionário de símbolos. Rio de Janeiro: José Olympio Editora, 1989.

HANSEN, João Adolfo. Alegoria: construção e interpretação da metáfora. São Paulo: Atual, 1986.

“Agudezas seiscentistas". Revista Letras: Literatura e pensamento entre o final da Renascença, o Barroco e a Idade Clássica, Santa Maria, n. 24, p. 57-72, 2002.

HOCKE, Gustav René. Maneirismo na literatura. Trad.: Fernando de Moraes Barros. São Paulo: Perspectiva, 2011. 
LAUSBERG, Heinrich. Elementos de retórica literária. Trad.: R. M. Rosado Fernandes. Lisboa: Fundação Calouste Gulbenkian, 2011.

MALEVAL, Maria do Amparo Tavares. Fernão Lopes e a retórica medieval. Niterói: Editora da Universidade Federal Fluminense, 2010.

SARAIVA, António José. O discurso engenhoso. São Paulo: Perspectiva, 1980.

TOBIAS. In: BÍBLIA Sagrada. São Paulo: Paulinas, 1977. Cap. 6, vers. 1-9, p. 487.

VIEIRA, António. Sermões Hagiográficos I. São Paulo: Edições Loyola, 2015. Obras Completas: t. II, v. X. 